\title{
Transmembrane Topology and Subcellular Distribution of the Benzodiazepine Receptor
}

\author{
Cynthia Czajkowski and David H. Farb \\ Department of Anatomy and Cell Biology, The State University of New York, Downstate Medical Center, \\ Brooklyn, New York 11203
}

\begin{abstract}
The distribution and transmembrane topology of benzodiazepine receptors were investigated in situ using intact and saponin-treated neurons of brain cell cultures. Reversible ligand binding and photoaffinity labeling, using ${ }^{3} \mathrm{H}$-flunitrazepam as a probe, were employed in conjunction with trypsin-induced exhaustive proteolysis and competition binding using a novel benzodiazepine (Ro7-0213) that contains a quaternary ammonium moiety bearing a full positive charge. About $80 \%$ of the benzodiazepine receptors, with apparent subunit molecular weights of 48,000 and 51,000 , are located in the surface membrane and contain one or more trypsin-sensitive sites exposed at the extracellular surface. The ligand recognition sites of the surface receptors are orientated toward the extracellular space and are sensitive to both competition by Ro7-0213 and trypsin attack. Approximately $20 \%$ of the receptors are intracellular or sequestered and are insensitive to both trypsin and competition by Ro7-0213 in intact cells. Strikingly, all of the ${ }^{3} \mathrm{H}$-flunitrazepam photolabeled sites inaccessible to competition by Ro70213 are also resistant to extracellular trypsin, but are sensitive to trypsin and Ro7-0213 in saponin-treated cells. This result provides strong evidence for protected receptors. Surface receptors are differentially sensitive to trypsin-induced inactivation such that $57 \%$ (of total) are inactivated, while $24 \%$ (of total) are cleaved but, surprisingly, retain the capacity to bind ${ }^{3} \mathrm{H}-\mathrm{flu}$ nitrazepam. The observation that the ability of the receptor fragment to bind ligand is unaltered demonstrates that the integrity of the benzodiazepine binding site is not contingent upon the presence of about half of the intact polypeptide chain. The receptor fragment, with an apparent molecular weight of 24,000 , is produced upon exposure to extracellular trypsin and remains anchored in the plasma membrane. The fragment also contains at least one trypsin-sensitive site that is exposed at the intracellular face of the plasma membrane. The results indicate that this receptor fragment is a transmembrane segment of the GABA/benzodiazepine receptor complex, in which the ligand recognition site faces extracellularly.
\end{abstract}

A question of central importance to understanding the structure and function of the GABA/benzodiazepine receptor complex (GABA/BZD-R) concerns its transmembrane topology and subcellular distribution. It is known that benzodiazepine drugs potentiate GABA responses determined on intact neurons in culture (Chan and Farb, 1985; Choi et al., 1977; Macdonald and Barker, 1978) or on isolated patches of adrenal chromaffin cell surface membrane (Bormann and Clapman, 1985) and that

\footnotetext{
Received Nov. 25, 1985; revised Mar. 11, 1986; accepted Mar. 18, 1986.

We thank Dr. Terrell Gibbs for many helpful discussions and for a critical reading of the manuscript. We also thank Ms. Inna Rozenberg for technical assistance. This work was supported by NIH (NS 18356) and New York Heart.

Correspondence should be addressed to Dr. David H. Farb, Department of Anatomy and Cell Biology, Box 5, State University of New York, Downstatc Medical Center, Brooklyn, NY 11203.

Copyright (C) 1986 Society for Neuroscience $0270-6474 / 86 / 102857-07 \$ 02.00 / 0$
}

postsynaptic densities fractionated from bovine brain are enriched in Type I benzodiazepine binding sites (Trifiletti and Snyder, 1985), indicating that some functional receptors are located in the plasma membrane. Similarly, it is known that photoaffinity labeling of intact brain cells with ${ }^{3} \mathrm{H}$-flunitrazepam yields labeled proteins with apparent molecular weights $\left(\mathrm{M}_{\mathrm{r}}\right)$ of 48,000 and 51,000 (Borden et al., 1984), similar to those observed in photolabeled membrane homogenates (Farb et al., 1984; Mohler et al., 1980; Sieghart and Karobath, 1980; Thomas and Tallman, 1981). However, it cannot be concluded that the benzodiazepine recognition site is exposed at the extracellular surface of the plasma membrane since benzodiazepines are lipophilic and would be expected to pass rapidly across the membrane.

Proteolytic enzymes have proved to be useful tools in studying the transmembrane orientation of membrane proteins by the simple fact that they are macromolecules that do not cross biological membranes. This approach has been used to gain an understanding of the structure and function of the nicotinic $\mathrm{ACh}$ receptor (Wennogle and Changeux, 1980) and the beta-adrenergic receptor (Strulovici and Lefkowiť, 1984). Similarly, compounds that carry a nonionizable full positive charge are also excluded by biological membranes and have been used to distinguish cell-surface from intracellular receptors for muscarinic ACh receptors (Maloteaux et al., 1983) and beta-adrenergic receptors (Hertel et al., 1983). As a first step toward elucidating the transmembrane topology and subcellular distribution of the GABA/BZD-R, we report here the results of experiments utilizing differential trypsinization of BZD-Rs in situ to determine (1) the distribution of membrane-associated BZD-Rs between the cell-surface and intracellular membrancs and (2) aspects of the transmembrane topology of the BZD-R. Additionally, we have used Ro7-0213, a positively charged BZD, to distinguish between cell-surface and intracellular BZD-Rs. We have determined that approximately $80 \%$ of the BZD-Rs are surface receptors with thcir ligand binding sites facing extracellularly. We have also identified a low-molecular-weight $\left(M_{r}=24,000\right)$ fragment of BZD-R that contains the intact ligand recognition site and spans the plasma membrane, such as might be expected for a transmembrane segment of receptor.

\section{Materials and Methods}

Benzodiazepines were a gift of Dr. P. Sorter of F. Hoffman-La Roche (Nutley, NJ). All other chemicals were obtained from commercial sources.

Neurons were dissociated from brain of $7 \mathrm{~d}$ chick embryos, plated on collagen-coated $100 \mathrm{~mm}$ plastic tissue culture dishes and maintained in culture for 1 week as described previously (Borden et al., 1984; Farb et al., 1979). Membrane homogenates prepared from $20 \mathrm{~d}$ embryonic chick brains $\left(20 \mathrm{~d} \mathrm{P}_{2}\right)$ were prepared as outlined in Chan et al. (1983) and Gibbs et al. (1985). For trypsinization, cultures were washed twice in $25 \mathrm{~mm}$ HEPES buffer containing $5.4 \mathrm{~mm} \mathrm{KCl}, 0.9 \mathrm{~mm} \mathrm{CaCl}_{2}, 0.4$ $\mathrm{mM} \mathrm{MgSO}_{4} \cdot 7 \mathrm{H}_{2} \mathrm{O}$, and $190 \mathrm{~mm}$ sucrose (pH 7.2). To trypsinize extracellular binding sites on intact cells, cultures were incubated for $90 \mathrm{~min}$ 


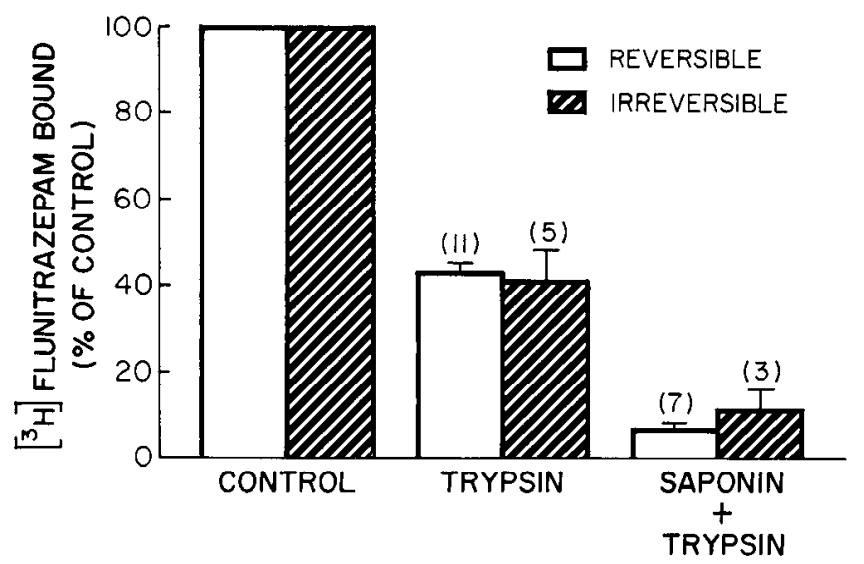

Figure 1. Effect of saponin on the sensitivity of BZD-R to trypsinization in situ. Data show the specific reversible and irreversible binding of ${ }^{3} \mathrm{H}$-flunitrazepam to homogenates prepared from trypsinized intact and saponin-treated cells in culture. Intact and saponin-treated brain cell cultures were incubated in the absence (control) or presence of 0.5 $\mathrm{mg} / \mathrm{ml}$ trypsin in HEPES buffer, $\mathrm{pH} 7.2$, for $90 \mathrm{~min}$ at $37^{\circ} \mathrm{C}$, soybean trypsin inhibitor was added, and cells were scraped from the culture dishes, centrifuged, resuspended in PBSS and the specific reversible (open bars) and irreversible (hatched bars) binding of $5 \mathrm{nM}{ }^{3} \mathrm{H}$-flunitrazepam was measured as described in Materials and Methods. Saponin treatment alone did not affect either the reversible $(101 \pm 7 \%, n=7)$ or irreversible $(105 \pm 14 \%, n=5)$ binding. Data points represent the mean \pm SEM of triplicate determinations, normalized to control. Numbers in the parentheses represent the number of separate experiments.

(unless otherwise indicated) at $37^{\circ} \mathrm{C}$ with or without $0.5 \mathrm{mg} / \mathrm{ml}$ bovine pancreas trypsin (Sigma) in the above buffer. To expose trypsin-resistant binding sites, cells were either (1) scraped from culture dishes, homogenized, and then incubated in trypsin, or (2) treated for $3 \mathrm{~min}$ with $0.5 \%$ saponin in $20 \mathrm{~mm}$ sodium phosphate buffer, pH 7.2, with $300 \mathrm{~mm}$ sucrose (Fambrough and Devreotes, 1978) and washed twice with HEPES buffer prior to incubation in trypsin. Trypsin activity was terminated by placing the incubations on ice and adding soybean trypsin inhibitor $(0.5 \mathrm{mg} / \mathrm{ml}$, final concentration). Cells were scraped from culture dishes, homogenized, and centrifuged at $30,000 \times g$ for $20 \mathrm{~min}$. The resulting pellets were resuspended in a phosphate-buffered Earle's balanced salt solution (PBSS; pH 7.4) and the reversible and irreversible binding of $5 \mathrm{~nm}{ }^{3} \mathrm{H}$-flunitrazepam determined as described below. In a control experiment, $0.5 \mathrm{mg} / \mathrm{ml}$ soybean trypsin inhibitor was added to intact cultures simultaneously with trypsin, and the cultures were incubated for $90 \mathrm{~min}$ at $37^{\circ} \mathrm{C}$. The soybean trypsin inhibitor prevented the cleavage of the photolabcled subunits, and no change in binding of $5 \mathrm{~nm}{ }^{3} \mathrm{H}-$ flunitrazepam was observed. These results indicate that this amount of inhibitor prevented trypsin action.

To measure reversible binding, aliquots of culture homogenates were incubated with $5 \mathrm{~nm}{ }^{3} \mathrm{H}$-flunitrazepam (New England Nuclear) for 60 min at $4^{\circ} \mathrm{C}$ in PBSS. The incubation was terminated by filtration through Whatman GF/B glass fiber filters, which were then washed 4 times with a total of $20 \mathrm{ml}$ of buffer. Radioactivity remaining on the filters was determined by liquid scintillation counting. In all experiments, $1 \mathrm{~mm}$ flurazepam was used to determine nonspecific binding, which was subtracted from total binding to yield the specific component.

Photoaffinity labeling of intact cultures and culture homogenates with flunitrazepam was carried out according to procedures described previously (Borden et al., 1984; Chan et al., 1983). Briefly, cultures were rinsed 2 times with ice-cold PBSS using a total volume of $10 \mathrm{ml}$ and photolabeled by incubation with $5 \mathrm{nM}{ }^{3} \mathrm{H}$-flunitrazepam $\left(30 \mathrm{~min}, 4^{\circ} \mathrm{C}\right.$, in PBSS) followed by irradiation with long-wavelength ultraviolet light (General Electric F40 BLB bulb) for $45 \mathrm{~min}$ at $4^{\circ} \mathrm{C}$. Intact cells were washed with ice-cold PBSS, scraped from culture dishes, and homogenized in buffer. The homogenates were then centrifuged at 30,000 $\times$ $g$ for $20 \mathrm{~min}$, and the resulting pellets were resuspended in PBSS containing $1 \mathrm{~mm}$ flurazepam, incubated for $45 \mathrm{~min}$; and aliquots were either used to measure cell-associated radioactivity by filtration assay through Whatman GF/B filters, or solubilized in SDS "stop solution" containing 0.0625 м Tris- $\mathrm{HCl}$ (pH 6.8), 2\% SDS, $10 \%$ glycerol, $5 \%$ 2-mercapto-

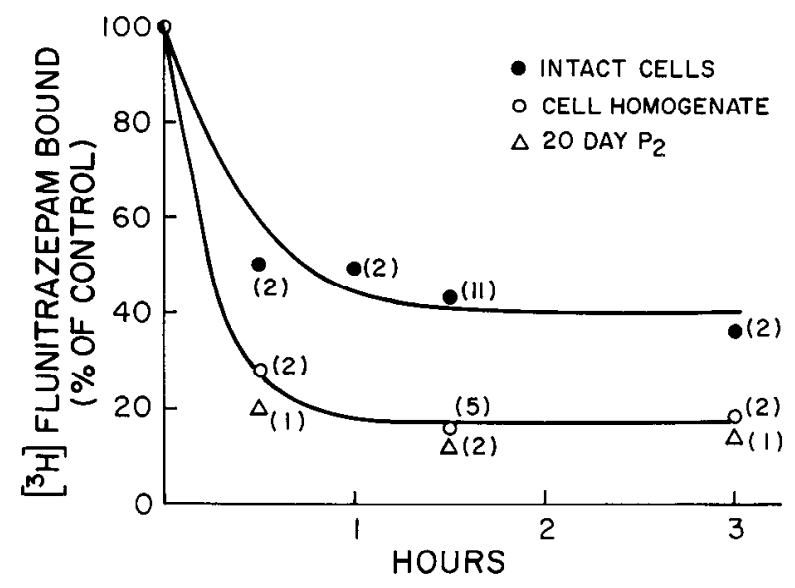

Figure 2. Time course for trypsin-induced inactivation of the specific reversible binding of ${ }^{3} \mathrm{H}$-flunitrazepam to trypsin-treated intact cells and trypsin-treated homogenates. Intact cells $(\bullet)$ and membrane homogenates prepared from either brain cell cultures $(0)$ or $20 \mathrm{~d} \mathrm{P}_{2}(\triangle)$ were incubated in the absence (control) or presence of $0.5 \mathrm{mg} / \mathrm{ml}$ trypsin at $37^{\circ} \mathrm{C}$ in HEPES buffer for the indicated times and the reversible binding of $5 \mathrm{~nm}{ }^{3} \mathrm{H}$-flunitrazepam was measured as described in Materials and Methods. The numbers in the parentheses represent the number of separate experiments.

ethanol, and $0.001 \%$ bromophenol blue (tracking dye). Photolabeling of culture homogenates was carried out according to a similar protocol. In some samples, $1 \mathrm{~mm}$ flurazepam was included during the photolabeling procedure to determine nonspecific photolabeling.

SDS-PAGE was performed according to the method of Laemmli (1970). The samples were boiled for $3 \mathrm{~min}$ in SDS stop solution before application to $10 \%$ polyacrylamide gels. The following proteins, obtained from Bio-Rad, were used as molecular-weight standards: phosphorylase $\mathrm{B}\left(\mathrm{M}_{\mathrm{r}}=92,000\right)$, BSA $\left(\mathrm{M}_{\mathrm{r}}=66,200\right)$, ovalbumin $\left(\mathrm{M}_{\mathrm{r}}=45,000\right)$, carbonic anhydrase $\left(M_{r}=31,000\right)$, soybean trypsin inhibitor $\left(M_{r}=21,500\right)$, and lysozyme $\left(M_{r}=14,400\right)$. Following electrophoresis, gels were processed by either of 2 methods:

Method $a$. Gels were fixed and stained with a solution of $0.4 \% \mathrm{CoO}-$ massie brilliant blue solution in 50\% methanol-7\% acetic acid and destained by repeated washings in $7 \%$ acetic acid. The amount of radioactivity associated with the separated proteins was determined by cutting each gel lane into $1 \mathrm{~mm}$ slices, dissolving the slices with $0.5 \mathrm{ml}$ of $50 \%$ hydrogen peroxide overnight at $43^{\circ} \mathrm{C}$, and determining the radioactivity associated with each slice by liquid scintillation counting.

Method $b$. Immediately following electrophoresis, individual gel lanes were cut out of the slab gel, frozen with dry ice, and stored at $-70^{\circ} \mathrm{C}$ prior to cutting into $1 \mathrm{~mm}$ slices. Radioactivity was eluted from the gel slices with $0.5 \mathrm{ml}$ of a solution containing $1 \%$ SDS, $0.025 \mathrm{M}$ Tris, and $0.0625 \mathrm{M}$ glycine ( $\mathrm{pH} 8.3$ ). The radioactivity associated with each slice was determined by liquid scintillation counting. The distribution of radioactivity within the gels was similar for the 2 processing methods.

\section{Results}

\section{Effect of trypsin on $B Z D-R$ binding}

Following trypsin-induced exhaustive proteolysis of intact brain cell cultures, the binding of ${ }^{3} \mathrm{H}$-flunitrazepam was reduced significantly. There was a similar reduction in reversible and UVinduced irreversible ${ }^{3} \mathrm{H}$-flunitrazepam binding, with $43 \pm 7 \%$ $(n=11)$ of the reversible and $41 \pm 7 \%(n=5)$ of the irreversible binding remaining resistant to trypsin (Figs. 1, 2) following a 90 min incubation. Thus, about $42 \%$ of the binding is protected from trypsin attack. Addition of fresh trypsin after 60 min of incubation did not change the amount of trypsin-resistant binding. No further reduction was observed when trypsin treatment was extended to $3 \mathrm{hr}$. Thus, a $90 \mathrm{~min}$ incubation time for trypsin treatment was routinely chosen to ensure that trypsinization was exhaustive. Soybean trypsin inhibitor $(0.5 \mathrm{mg} / \mathrm{ml}$, final concentration) completely blocked the effect of trypsin. 


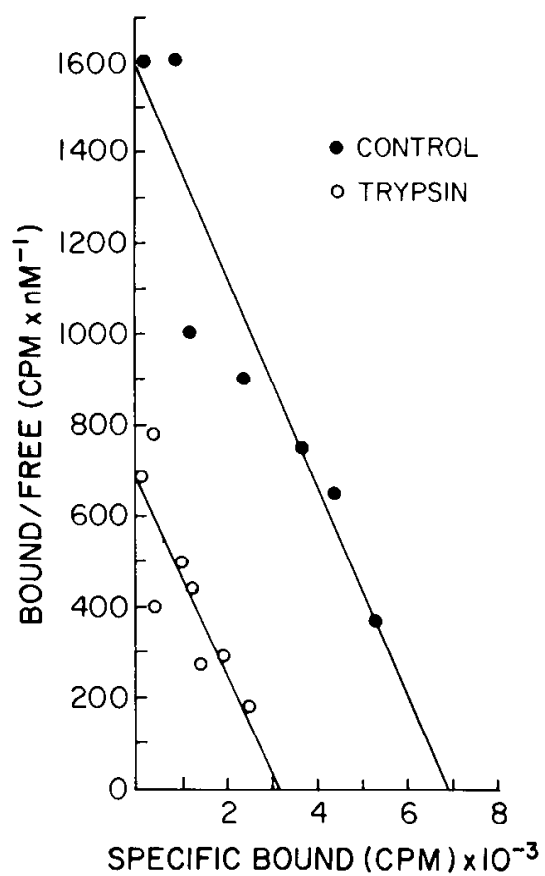

Figure 3. Saturation binding of ${ }^{3} \mathrm{H}$-flunitrazepam to homogenates prepared from control (0) and trypsin-treated (o) brain cell cultures. Cells were incubated in the absence or presence of $0.5 \mathrm{mg} / \mathrm{ml}$ trypsin in HEPES buffer for $90 \mathrm{~min}$ at $37^{\circ} \mathrm{C}$. Binding was determined as described in Materials and Methods. Scatchard plots of the data are shown. Lines through the data points represent the best fit determined by linearregression analysis, and each data point represents the mean of triplicate determinations. For control: $K_{\mathrm{D}}=4.4 \mathrm{nM}, B_{\max }=6800 \mathrm{cpm}$; in trypsintreated: $K_{\mathrm{D}}=4.8 \mathrm{nM}, B_{\max }=3200 \mathrm{cpm} . B_{\max }$ data are not expressed on a per milligram protein basis since trypsinization causes a loss in general cell protein as well as a loss of BZD-R. Thus, expressing the data on a per milligram basis would not reflect the absolute sensitivity of the BZD-R to trypsin.

In order to determine whether the loss in binding following trypsinization of intact cells reflected a real loss in receptor number or a change in binding affinity for flunitrazepam, we performed both saturation and competition binding experiments on mombrane homogenates derived from trypsinized intact cells. As demonstrated in Figure 3, trypsin-induced cleavage of the BZD-R of intact cells reduced the number of ${ }^{3} \mathrm{H}$-flunitrazepam binding sites $\left(B_{\max }:\right.$ control $=6800 \mathrm{cpm}$; trypsinized $=$ $3200 \mathrm{cpm}$ ), whereas binding affinity was virtually unchanged (Fig. 4). In addition, GABA stimulation of reversible ${ }^{3} \mathrm{H}-\mathrm{flu}$ nitrazepam binding was observed both before and after treatment of cells with trypsin.

The reduction in BZD-R number observed following trypsin treatment is probably not due to cell death or plasmalemma disruption since trypsin itself does not appear to cause cell death or membrane leakiness. When cultures were first treated with trypsin and then exposed to trypan blue, a vital dye, the number of cells that excluded dye in treated cultures $(86 \pm 1 \%, n=$ 2,530 cells counted) was identical to untreated cultures $(86 \%$, $n=2,465$ cells counted).

To determine if the intact plasma membrane protected intracellularly directed binding sites of surface receptors and/or binding sites of intracellular receptors, cells were homogenized prior to trypsinization. Figure 2 shows that prior homogenization exposed additional $(27 \%)$ benzodiazepine receptors to enzymatic digestion. The trypsin-resistant reversible binding was $22 \pm 1 \%(n=5)$ when cells were first homogenized (20 strokes of Dounce) and then trypsinized (90 $\mathrm{min}) ; 15 \%(n=2)$ when homogenates of cells were frozen, thawed, and then tryp-

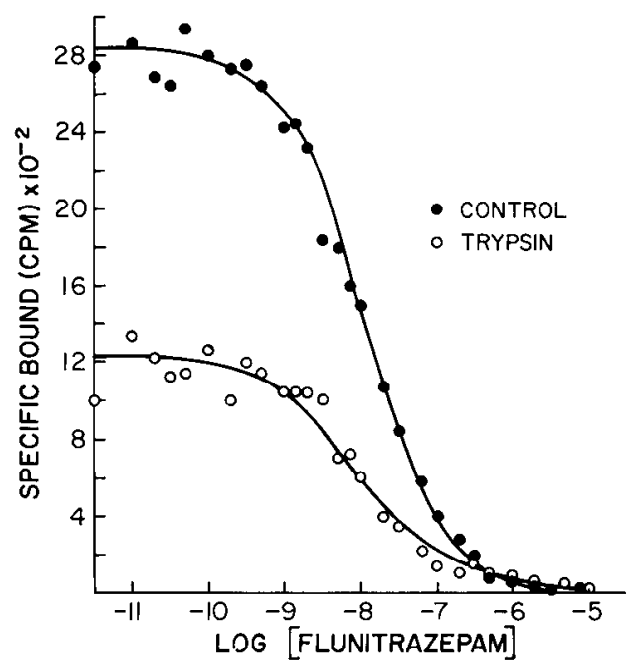

Figure 4. Competitive binding of flunitrazepam and ${ }^{3} \mathrm{H}$-flunitrazepam to homogenates prepared from control $(\bullet)$ and trypsin-treated $(0)$ brain cells. Cells were incubated for $90 \mathrm{~min}$ at $37^{\circ} \mathrm{C}$ in the absence or presence of $0.5 \mathrm{mg} / \mathrm{ml}$ trypsin in HEPES buffer. Binding assays were performed as described in Materials and Methods using $5 \mathrm{nM}{ }^{3} \mathrm{H}$-flunitrazepam (nonspecific binding in $1 \mathrm{~mm}$ flurazepam was subtracted). Each data point is the mean of triplicate determinations. $K_{\mathrm{I}}$ 's $=5.4 \mathrm{nM}$ and 6.2 $\mathrm{nM}$ for control and trypsin-treated cultures, respectively.

sinized; and $16 \pm 2 \%(n=11)$ when cells were homogenized morc cxtcnsively (100 strokes) before exposure to trypsin. Similar results were obtained with $P_{2}$ homogenates of $20 \mathrm{~d}$ embryonic brain ( $12 \pm 2 \%$ resistant, $n=2)$. Irreversible binding of ${ }^{3} \mathrm{H}$-flunitrazepam to trypsin-treated culture homogenates likewise was reduced, with only $16 \%$ of the binding remaining resistant.

Permeabilization of the plasmalemma with saponin also increased the effect of trypsin, rendering most of the previously trypsin-resistant binding trypsin-sensitive; saponin alone had no effect on binding (Fig. 1, legend). Once again, reversible and irreversible binding were reduced proportionately, with $11 \%$ of the irreversible and $7 \%$ of the reversible binding resistant to inactivation by treatment with saponin and trypsin.

The observation that trypsinization of both saponin-treated cells and cellular homogenates results in the inactivation of most of the benzodiazepine binding sites argues that the amount of trypsin-resistant binding seen in intact cells is not a result of inactive (autodigested) trypsin.

FLUNITRAZEPAM (RO5-4200)

QUATERNIZED BZD (Ro7-0213)<smiles>CN1C(=O)CN2Cc3cc([N+](=O)[O-])ccc3C(c3ccccc3F)=C21</smiles><smiles>C[N+](C)(C)CCN1C(=O)CN=C(c2ccccc2)c2cc(Cl)ccc21</smiles>

Figure 5. Structures of flunitrazepam and the quaternized benzodiazepine, Ro7-0213. 


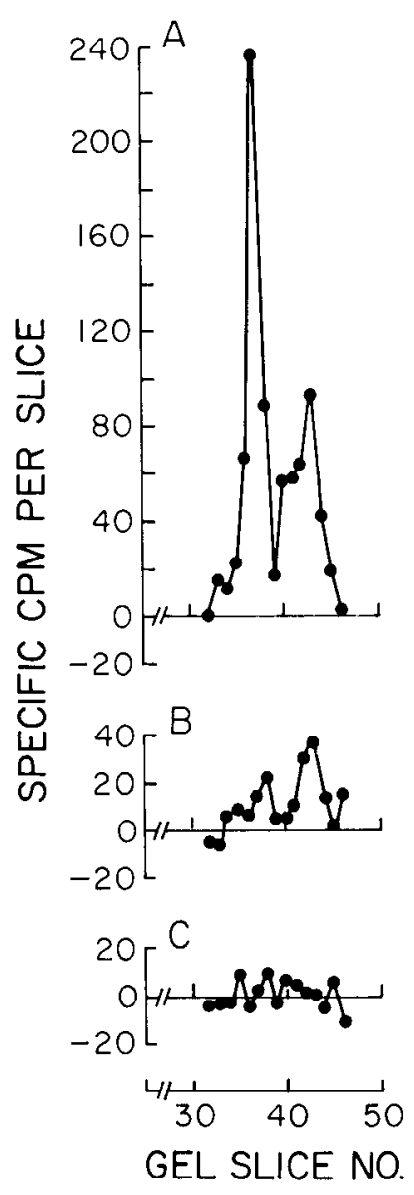

Figure 6. A quaternized BZD (Ro7-0213) gains access to previously inaccessible BZD-Rs after exposure of cells to saponin. Intact $(A, B)$ and saponin-treated $(C)$ cells were photolabeled with $5 \mathrm{nM}{ }^{3} \mathrm{H}$-flunitrazepam (10 min UV) in the absence $(A)$ and presence of $30 \mu \mathrm{M} \mathrm{Ro7-}$ $0213(B, C)$ and preparcd for SDS-PAGE. The distribution of radioactivity in the $M_{\mathrm{r}}=51,000$ and 48,000 subunits is shown. This experiment was repeated 2 times with similar results.

\section{Effect of Ro7-0213 on ${ }^{3} \mathrm{H}$-flunitrazepam binding}

As a further test of the hypothesis that there is a population of BZD binding sites that is inaccessible from the extracellular medium, experiments were carried out using the quaternized benzodiazepine, Ro7-0213, to determine directly the amount of cell surface BZD-Rs. Since Ro7-0213 bears a full positive charge, it would not be expected to cross the plasma membrane (Fig. 5). Photoaffinity labeling of intact cells with $5 \mathrm{nM}{ }^{3} \mathrm{H}-$ flunitrazepam in the presence of $30 \mu \mathrm{M}$ Ro7-0213 $\left(K_{\mathrm{I}}=300\right.$
nM) resulted in a $78.5 \pm 0.5 \%(n=2)$ reduction in the amount of specific irreversible binding (Fig. 6). Thus, about $20 \%$ of the specific irreversible binding is protected from competition by Ro7-0213 in intact cells. All of these sites were also resistant to extracellular trypsin. When cultures were first treated with saponin and then photolabeled in the presence of $30 \mu \mathrm{M} \mathrm{Ro7-}$ 0213 , virtually all of the irreversible binding sites were sensitive to competition by the quaternized benzodiazepine $(93.5 \pm 5.5 \%$, $n=2)$.

\section{$S D S-P A G E$ of the trypsinized $B Z D-R$}

The discrepancy observed between the fraction of ${ }^{3} \mathrm{H}$-flunitrazepam binding resistant to trypsin (ca. 40\%) and the fraction of irreversible binding inaccessible to competition by Ro7-0213 (ca. 20\%) suggested that not all of the trypsin-resistant binding measured by filtration was intracellular. Thus, either $20 \%$ of the sites were surface receptors and protected from trypsin but accessible to Ro7-0213, or $20 \%$ of the sites were cleaved by trypsin but retained their ability to bind ${ }^{3} \mathrm{H}$-flunitrazepam. To distinguish these hypotheses, homogenates derived from trypsinized cells were photolabeled and subjected to SDS-PAGE. Trypsinization of intact cells generated a new, lower molecular weight $\left(M_{r}=24,000\right)$ peak in addition to the remaining $M_{r}=48,000$ and 51,000 proteins (Fig. 7, $n=3$ ). The same pattern of radiolabeled proteins was obtained when cultures were first photolabeled and then treated with trypsin $(n=3)$. It will be interesting to determine whether the $\mathrm{M}_{\mathrm{r}}=24,000$ trypsin-generated fragment is derived from one or both of the $M_{r}=51,000$ and 48,000 labeled proteins. The recovery of the specific photolabeling in these 3 proteins $\left(M_{r}=51,000,48,000\right.$, and 24,000) was $43 \pm 5 \%(n=6)$ of that present initially in the $M_{r}=48,000$ and 51,000 subunits. This compares favorably with the value of $41 \pm 7 \%$ ( 5 experiments in triplicate) obtained for trypsinresistant photolabeling as measured by filter binding (Fig. 1). Thus, the binding measured by filtration is composed of 2 components: binding associated with a trypsin-generated fragment of the BZD-R and binding associated with intact BZD-Rs. Significantly, the specific radioactivity remaining in the $M_{r}=51,000$ and 48,000 BZD-R proteins following trypsinization was $19 \pm$ $4 \%(n=6)$ of control. This is similar to the amount of irreversible binding resistant to competition by the quaternized BZD, Ro7-0213 (ca. 20\%, Fig. 6). The $M_{r}=24,000$ trypsingenerated fragment contained $24 \pm 2 \%(n=6)$ of the radioactivity initially present in the $\mathrm{M}_{\mathrm{r}}=48,000$ and 51,000 proteins (Table 1). Finally, either homogenization or exposure of neuronal cells to saponin before trypsinization decreased substantially (ca. 59\%) the amount of radioactivity that migrated with a $M_{r}=24,000$ (Figs. 7, 8). The above results indicate that trypsinization generates a receptor fragment of $\mathrm{M}_{\mathrm{r}}=24,000$ and that this fragment contains the ligand recognition site and has a transmembrane domain. Additionally, in intact cells, a similar fraction of BZD-Rs are inaccessible to both trypsin and the

Table 1. Trypsin sensitivity of the benzodiazepine receptor (specific binding remaining as percentage of control)

\begin{tabular}{|c|c|c|c|c|c|}
\hline \multirow[b]{2}{*}{ Treatment } & \multicolumn{2}{|l|}{ Filtration assay } & \multicolumn{3}{|l|}{ SDS-PAGE } \\
\hline & Reversible & Irreversible & $51+48+24^{a}$ & $51+48$ & 24 \\
\hline None (control) & $100 \%$ & $100 \%$ & $100 \%$ & $100 \%$ & $0 \%$ \\
\hline Trypsin & $43 \pm 2 \%(11)$ & $41 \pm 7 \%(5)$ & $43 \pm 5 \%(6)$ & $19 \pm 4 \%(6)$ & $24 \pm 2 \%(6)$ \\
\hline Saponin + trypsin & $7 \pm 1 \%(7)$ & $11 \pm 5 \%$ & $15 \pm 4 \%$ & $5 \pm 3 \%(5)$ & $10 \pm 3 \%(5)^{b}$ \\
\hline
\end{tabular}

Intact and saponin-treated cells were incubated in the absence (control) and presence of $0.5 \mathrm{mg} / \mathrm{ml}$ trypsin $\left(90 \mathrm{~min}, 37^{\circ} \mathrm{C}\right)$ and the specific reversible and irreversible binding of $5 \mathrm{nM}{ }^{3} \mathrm{H}$-flunitrazepam was measured by filtration assay and SDS-PAGE. Values represent the specific binding observed relative to that observed in the absence of trypsin, expressed as a percentage. Numbers in the parentheses represent the number of individual experiments.

a 51, 48, and 24 represent $M_{r}=51,000,48,000$, and 24,000, respectively.

${ }^{b}$ Percentages were determined from the summed cpm in gel slices corresponding to the position of the $M_{r}=24,000$ peak. However, counts appeared uniformly distributed above baseline and did not form a true peak. 

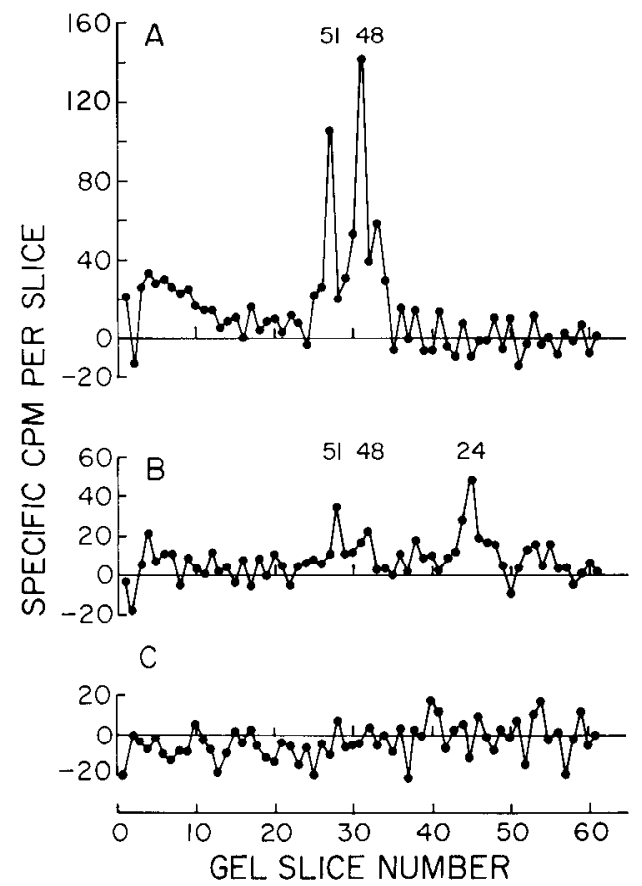

Figure 7. Trypsinization of intact cells and saponin-treated cells reveals membrane-protected BZD-Rs. Data shown are the results of SDSPAGE of photolabeled and trypsinized cells. Cells were incubated for $90 \mathrm{~min}$ at $37^{\circ} \mathrm{C}$ in the absence $(A)$ or presence $(B)$ of $0.5 \mathrm{mg} / \mathrm{ml}$ trypsin in HEPES buffer. Trypsin activity was terminated by placing the dishes on ice and adding soybean trypsin inhibitor. The cells were homogenized and centrifuged, and the pellet was resuspended in PBSS, photolabeled with $5 \mathrm{nM}^{3} \mathrm{H}$-flunitrazepam and then subjected to SDS-PAGE. The gels were sliced into $1 \mathrm{~mm}$ slices and eluted with $\mathrm{H}_{2} \mathrm{O}_{2}$; the radioactivity associated with each slice was determined by scintillation counting. In control cultures $(A)$, no trypsin was present during the incubation, and 2 peaks of $\mathrm{M}_{\mathrm{r}}-51,000$ and 48,000 were seen. Following trypsin treatment of intact cells $(B)$, a third peak, $M_{r}=24,000$, was also present. When cells were treated with saponin $(0.5 \%)$ and then trypsinized $(C)$ no peaks were detectable. Results are from a single experiment, which was repeated 3 times with similar results. The same results were observed when cells were photolabeled and then treated with trypsin $(n=$ 3). Numbers represent $M_{r} \times 10^{-3}$. The peaks observed at $M_{r}=51,000$, 48,000 , and 24,000 were seen in every experiment $(n=6)$. The small positive and negative deflections from the baseline observed were seen inconsistently from experiment to experiment and represent random "noise."

quaternized benzodiazepine, Ro7-0213, suggesting that in both methods the same population of BZD-Rs is being examined.

\section{Discussion}

Little is known about the organization of neurotransmitter receptors at central synapses, and determining the relationship of receptor structure and transmembrane topology to receptor function is important to understanding the fundamental mechanisms of chemical synaptic transmission. Until recently, only 2 general kinds of receptor-effector systems were known, as exemplified by (1) the nicotinic ACh receptor, which contains an integral effector, and (2) the muscarinic $\mathrm{ACh}$ receptor and beta-adrenergic receptor, which do not have integral effector mechanisms but are coupled to transducing systems such as the enzyme adenylate cyclase. The GABA receptor, which contains a benzodiazepine-sensitive modulator site that may be on the same polypeptide chain as the GABA site (Schoch et al., 1985; Sigel et al., 1982), represents a novel receptor system, and the question of the relationship of receptor structure to function is an important one.

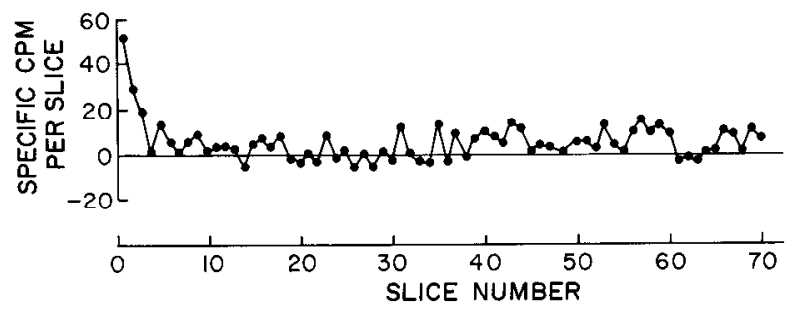

Figure 8. Trypsinization of cell homogenates reveals no labeled BZDRs. Results of SDS-PAGE of photolabeled, trynsinized culture homogenates are shown. Membrane homogenates prepared from brain cell cultures were incubated in $0.5 \mathrm{mg} / \mathrm{ml}$ trypsin for $90 \mathrm{~min}$ at $37^{\circ} \mathrm{C}$ in HEPES buffer. The enzyme reaction was terminated by placing the incubations on ice and adding soybean trypsin inhibitor. The homogenates were centrifuged and the pellets were resuspended in PBSS, photolabeled with $5 \mathrm{~nm}^{3} \mathrm{H}$-flunitrazepam, and then subjected to SDS-PAGE. No detectable peaks were observed.

The main conclusions of this study relate to the transmembrane topology and subcellular distribution of the GABA BZD-R. Exhaustive proteolysis by trypsin of intact neuronal cell cultures from embryonic chick brain demonstrates that $43 \%$ of the benzodiazepine binding sites are resistant to, whilc $57 \%$ are inactivated by, trypsinization at the extracellular surface of the plasma membrane. This reduction in binding is due to a decrease in receptor number (Figs. 3, 4). Two types of cell surface receptors can be distinguished based on their differential sensitivity to inactivation by trypsin: those that are inactivated completely by trypsin ( $57 \%$ of total) and others that are cleaved ( $24 \%$ of total) but retain binding activity. The fact that some of the surface binding sites are inactivated quickly while others are cleaved but not inactivated could be due to heterogeneity among the surfacc benzodiazcpine receptors, heterogeneity of receptor subunits, or heterogeneity of cells. In primary neuronal cell cultures different neuronal cell types are present. It is not yet clear whether this difference in the sensitivity to trypsin derives from a single kind of receptor with multiple nonidentical or asymmetrical sites, or from preexisting differences among surface receptors. These results, suggesting receptor heterogeneity, may explain the biphasic kinetics of BZD-R degradation (Borden et al., 1984), as well as other forms of receptor heterogeneity reported (Lo et al., 1982; Sieghart et al., 1983).

The observation that cell disruption by either extensive homogenization or saponin treatment causes some of the previously trypsin-resistant ${ }^{3} \mathrm{H}$-flunitrazepam binding to become trypsin-sensitive supports the argument that a large fraction of the potentially trypsin-sensitive benzodiazepine binding sites are protected by the plasmalemma. There are at least 3 possible explanations for these results: (1) the neurons might contain an internal pool of receptors; (2) the segment of receptor on which the ligand recognition site resides might contain a membraneembedded domain, spanning the membrane and sensitive to trypsin attack at its cytoplasmic face; or (3) trypsinization might stimulate sequestration or internalization of BZD-Rs, protecting them from further proteolysis.

Competition studies performed on intact cells, using the quaternized benzodiazepine Ro7-0213, also suggest the existence of both surface and internal benzodiazepine binding sites (Fig. 6). In the presence of a saturating concentration of Ro7-0213, approximately $20 \%$ of the specific irreversible ${ }^{3} \mathrm{H}$-flunitrazepam binding is resistant to competition and may represent internal and/or sequestered BZD-Rs. These sites are also trypsin-resistant. This result indicates that trypsin does not cross the plasma membrane. The observation that $80 \%$ of the binding is sensitive to competition by the quaternized benzodiazepine strongly suggests that these sites face extracellularly and are associated with cell-surface BZD-Rs. In electrophysiological experiments, Ro7- 


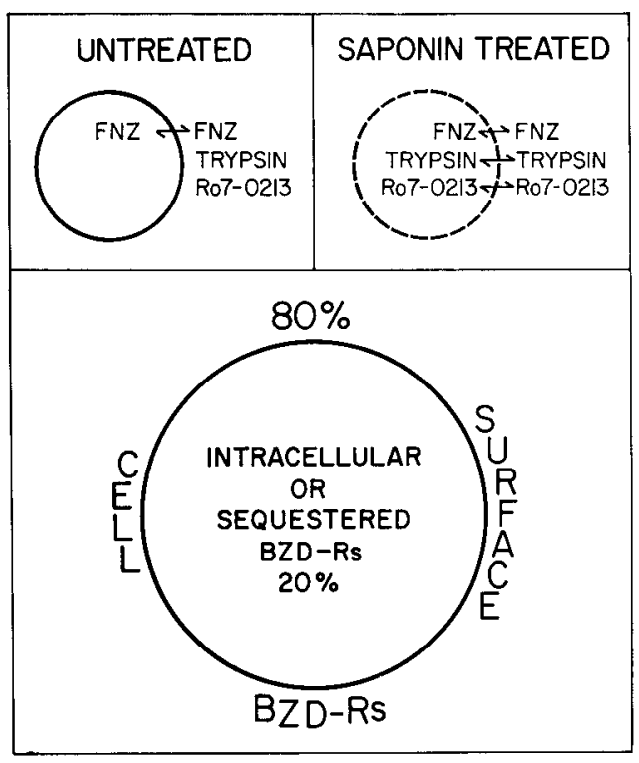

Figure 9. Model of the subcellular distribution of the BZD-R is shown. Eighty percent of the BZD binding sites are susceptible to both trypsin attack and competition by the quaternized BZD, Ro7-0213, and are represented as cell-surface BZD-Rs containing their ligand recognition sites facing extracellularly. Trypsin and Ro7-0213 cannot readily cross the plasma membrane and have access only to these extracellularly directed binding sites. Twenty percent of the hinding sites are protected by the intact plasma membrane from both trypsin and Ro7-0213 and probably represent BZD-Rs associated with intracellular membranes. Flunitrazepam (FNZ), a typical BZD, is lipophilic and has access to both sides of the plasmalemma. Following saponin treatment, the plasma membrane is disrupted, and trypsin, Ro7-0213, and flunitrazepam all have access to both sides of the plasma membrane.

0213 potentiates the GABA-mediated chloride conductance in chick spinal cord neurons in culture (D. Mierlak, unpublished observations), further pointing to the presence of functional cellsurface BZD-Rs. Following permeabilization of the plasmalemma with saponin, all of the BZD binding sites become sensitive to competition by Ro7-0213. These results are in agreement with those obtained from trypsinization experiments using cell homogenates and saponin-treated cells and provide additional evidence that saponin is affecting the integrity of the plasmalemma and not directly affecting the BZD-R.

SDS-PAGE of trypsinized and photolabeled intact cells reveals a decrease in labeling of the normally observed $M_{r}=$ 51,000 and 48,000 receptor subunits (approximately $20 \%$ remaining) and the appearance of a smaller receptor fragment that retains its recognition site for flunitrazepam and can be photolabeled subsequent to trypsin treatment (approximately 20\% of control labeling; Table 1, Fig. 7). Thus, the reversible and irreversible binding mcasurce by filtration following trypsinization of intact cells (approximately $40 \%$ of control) represent both intact benzodiazepine receptors and a membrane-associated trypsin-generated fragment of the receptor that retains the ligand binding site. Following disruption of the plasmalemma, the trypsin-resistant binding sites become trypsin-sensitive and the $M_{r}=24,000$ fragment is not observed (Figs. 7, 8). This suggests that the receptor fragment is a transmembrane segment of the BZD-R.

A similar trypsin-generated fragment has been reported when photolabeled rat brain homogenates were exposed to proteolytic enzymes (Eichinger and Sieghart, 1985; Klotz et al., 1984). In these studies, trypsin only partially inactivated the benzodiazepine binding sites. This is in contrast to the results reported here using both trypsinized culture homogenates and homogenates
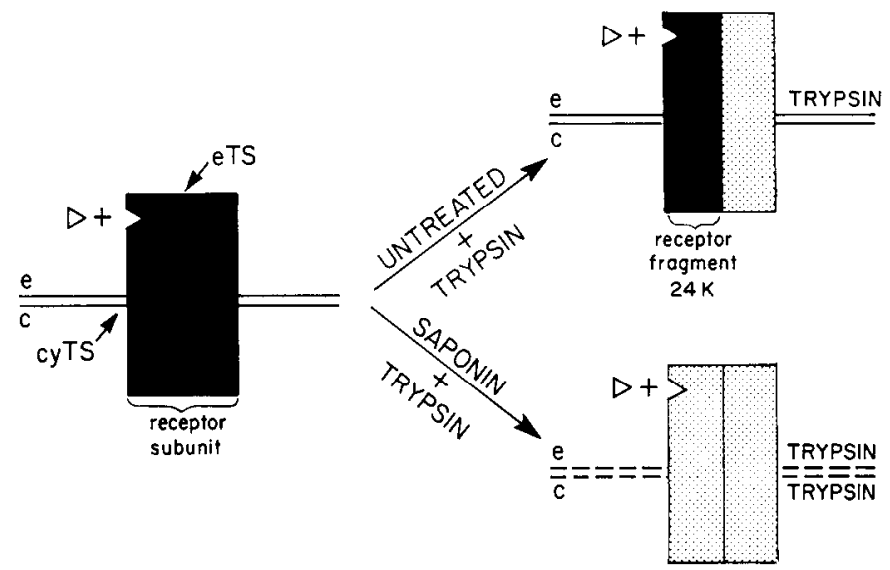

Figure 10. Model depicting the generation of the $\mathrm{M}_{\mathrm{r}}=24,000$ transmembrane BZD-R fragment. Following trypsinization of intact cells, a $M_{r}=24,000$ receptor fragment is generated from either one or both of the original receptor subunits $\left(M_{r}=51,000\right.$ and 48,000$)$, indicating the presence of at least one extracellular trypsin-sensitive site (eTS) on the subunits. The fragment retains BZD binding activity and remains associated with the plasma membrane. The $M_{r}=24,000$ receptor fragment is not observed following trypsin treatment of saponin-treated cells or cell homogenates, indicating that it spans the plasma membrane and contains a cytoplasmic trypsin-sensitive site (cyTS). The solid shading represents receptor proteins that exhibit binding activity and are measured under our electrophoretic conditions; stippling represents the trypsin-cleaved fragments of the BZD-R that are not measured by our techniques and may or may not be associated with the plasma membrane; $e$ and $c$ represent the extracellular and cytoplasmic side of the plasmalemma, respectively.

prepared from 20-d-old chick brains. The discrepancy may be due to differences in experimental conditions, such as homogenization techniques, membrane protein concentration, buffer, temperature, trypsin concentration, and time of incubation in trypsin. In principle, purified membranes form closed vesicles in vitro and proteases attack the proteins exposed on the outside of these vesicles exclusively. The vesicles, once formed, can be disrupted to varying degrees by different experimental conditions, e.g., warming, vigorous mechanical agitation, sonication, freezing-thawing, and hypo-osmotic treatment (Whittaker, 1969). Thus, the difference in protease sensitivity observed by Eichinger and Sieghart (1985) using rat brain homogenates compared to our results using culture and 20-d-old chick brain homogenates may be due to different experimental conditions during membrane homogenate preparation, resulting in varying amounts of sealed and unsealed vesicles. In the present study, exhaustive trypsinization of intact cells, saponin-treated cells, and homogenates prepared from cell cultures was examined. By using intact cells in culture, the condition of the vesicles formed by homogenization is not an issue, and a closer approximation to the in vivo situation is achieved.

In summary, we conclude that approximately $80 \%$ of the BZD-Rs in intact cells are susceptible to trypsin attack and may represent surface receptors, while $20 \%$ are inaccessible to trypsin or Ro7-0213 and may represent sequestered or intracellular receptors (Fig. 9). Following trypsin treatment of intact cells, a cleaved receptor fragment of $M_{r}=24,000$ is generated. It remains anchored in the plasma membrane and retains the ability to bind ${ }^{3} \mathrm{H}$-flunitrazepam reversibly and irreversibly. After either saponin treatment or extensive homogenization, trypsin significantly degrades the fragment, indicating that it has a cytoplasmic domain as well as a cell-surface domain, as expected for a transmembrane segment of the BZD-R (Fig. 10). In situ trypsinization combined with the use of membrane-impermeable recognition site ligands for the benzodiazepine receptor should 
provide a useful tool for probing the structural features of the GABA/BZD-R involved in the processes of ligand binding and transduction as well as receptor turnover, assembly, and processing.

\section{References}

Borden, L. A., C. M. Czajkowski, C. Y. Chan, and D. H. Farb (1984) Benzodiazepine receptor synthesis and degradation by neurons in culture. Science 226: 857-859.

Bormann, J., and D. E. Clapman (1985) Gamma-aminobutyric acid receptor channels in adrenal chromaffin cells: A patch clamp study. Proc. Natl. Acad. Sci. USA 82: 2168-2172.

Chan, C. Y., and D. H. Farb (1985) Modulation of neurotransmitter action: Control of the $\gamma$-aminobutyric acid response through the benzodiazepine receptor. J. Neurosci. 5: 2365-2373.

Chan, C. Y., T. T. Gibbs, L. A. Borden, and D. H. Farb (1983) Multiple embryonic benzodiazepine binding sites: Evidence for functionality. Life Sci. 33: 2061-2069.

Choi, D. W., D. H. Farb, and G. D. Fischbach (1977) Chlordiazepoxide selectively augments GABA action in spinal cord cell cultures. Nature 269: 342-344.

Eichinger, A., and W. Sieghart (1985) Differential degradation of different benzodiazepine binding proteins by incubation of membranes from cerebellum or hippocampus with trypsin. J. Neurochem. 45: 219-226.

Fambrough, D. M., and P. N. Devreotes (1978) Newly synthesized acetylcholine receptors are located in the Golgi apparatus. J. Cell Biol. 76: 237-244.

Farb, D. H., D. K. Berg, and G. D. Fischbach (1979) Uptake and release of $\left[{ }^{3} \mathrm{H}\right]$ gamma-aminobutyric acid by embryonic spinal cord neurons in dissociated cell culture. J. Cell Biol. 80:651-661.

Farb, D. H., L. A. Borden, C. Y. Chan, C. M. Czajkowski, T. T. Gibbs, and G. D. Schiller (1984) Modulation of neuronal function through benzodiazepine receptors: Biochemical and electrophysiological studies of neurons in primary monolayer cell culture. Ann. N.Y. Acad. Sci. 435: 1-31.

Gibbs, T. T., C. Y. Chan, C. M. Czajkowski, and D. H. Farb (1985) Benzodiazepine receptor photoaffinity labeling: Correlation of function with binding. Eur. J. Pharmacol. 110: 171-180.

Hertel, C., P. Muller, M. Portenier, and M. Staehelin (1983) Determination of the desensitization of beta-adrenergic receptors by [3 H]CGP-12177. Biochem. J. 216: 669-674.

Klotz, K., A. Bocchetta, J. Neale, J. Thomas, and J. Tallman (1984)
Proteolytic degradation of neuronal benzodiazepine binding sites. Life Sci. 34: 293-299.

Laemmli, U. K. (1970) Cleavage of structural proteins during the assembly of the head of bacteriophage $T_{4}$. Naturc 227: 680-685.

Lo, M. M. S., S. M. Strittmatter, and S. H. Snyder (1982) Physical separation and characterization of two types of benzodiazepine receptors. Proc. Natl. Acad. Sci. USA 79: 680-684.

MacDonald, R. L., and J. L. Barker (1978) Benzodiazepines specifically modulate GABA-mediated postsynaptic inhibition in cultured mammalian neurons. Nature 271: 563-564.

Maloteaux, J.-M., A. Gossuin, P. J. Pauwels, and P. M. Laduron (1983) Short-term disappearance of muscarinic cell surface receptors in carbachol-induced desensitization. FEBS Lett. 156: 103-107.

Mohler, H., M. K. Battersby, and J. G. Richards (1980) Benzodiazepine receptor protein identified and visualized in brain tissue by a photoaffinity label. Proc. Natl. Acad. Sci. USA 77: 1666-1670.

Schoch, P., J. G. Richards, P. Haring, B. Takacs, C. Stahli, T. Staehelin, W. Haefely, and H. Mohlcr (1985) Co-localization of GABA- $\Lambda$ receptors and benzodiazepine receptors in the brain shown by monoclonal antibodies. Nature 314: 168-171.

Sieghart, W., and M. Karobath (1980) Molecular heterogeneity of benzodiazepine receptors. Nature 286: 285-287.

Sieghart, W., A. Mayer, and G. Drexler (1983) Properties of $\left[{ }^{3} \mathrm{H}\right]-$ flunitrazepam binding to different benzodiazepine binding proteins. Eur. J. Pharmacol. 88: 291-299.

Sigel, E., C. Mamalaki, and E. A. Barnard (1982) Isolation of a GABA receptor from bovine brain using a benzodiazepine affinity column. FEBS Lett. 147: 45-48.

Strulovici, B., and R. J. Lefkowitz (1984) Activation, desensitization, and recycling of frog erythrocyte beta-adrenergic receptors: Differential perturbation by in situ trypsinization. J. Biol. Chem. 259:43894395.

Thomas, J. W., and J. F. Tallman (1981) Characterization of photoaffinity labeling of benzodiazepine binding sites. J. Biol. Chem. 256: 9839-9842.

Trifiletti, R., and S. Snyder (1985) Localization of type 1 benzodiazepine receptors to postsynaptic densities in bovine brain. J. Neurosci. 5: 1049-1057.

Wennogle, L. P., and J. P. Changeux (1980) Transmembrane orientation of proteins present in acetylcholine receptor-rich membranes from Torpedo marmorata studied by selective proteolysis. Eur. J. Biochem. 106: 381-393.

Whittaker, V. P. (1969) The synaptosome. In The Handbook of Neurochemistry, A. Lajtha, ed., pp. 327-364, Plenum, New York. 